\title{
The influence of innovative digital technologies in education on the life quality of students during the pandemic
}

\author{
Svetlana G. Zakharova ${ }^{1}{ }^{*}$, Irina A. Kulagova ${ }^{1}$, Irina $V$. Makarycheva $^{1}$, Mariya $V$. Oranova ${ }^{1}$, \\ and Tatyana J. Rusakova ${ }^{1}$ \\ ${ }^{1}$ Lobachevsky State University of Nizhny Novgorod - National Research University, Institute of \\ Economics and Entrepreneurship, Department of Management and Public Administration, Nizhny \\ Novgorod, Russia
}

\begin{abstract}
This article substantiates the relevance of studies on estimation the life quality of students during forced implementation of online digital educational technologies. The article presents the main trends of program target approach to life quality of population subdivided by the subjects of socio-economic relations. The main positive changes are revealed in the students' life manifested during the pandemic upon obtaining online educational services, including elements related with digital competences: labor market demand, conditions of formation and implementation, amounts and desired forms, emerging opportunities, relations with professional environment and social institutions of communications, methods and technologies of digital content. Peculiar features of the most important educational elements of online technologies, which change students' lifestyle and quality of life, are considered in the frames of blended learning: event systems, storytelling systems, gamification systems. Positive and negative phenomena have been revealed on the basis of analysis of changes in students' life during total application of online technologies.

Keywords: life quality of population, digitization of education, innovative educational technologies, professional competences, pandemic.
\end{abstract}

\section{Introduction}

Life quality of students and other population of Russia depends on numerous factors. According to the program-target approach to management of life quality of population, the acting factors are subdivided by subjects of socio-economic relations (Fig. 1) [1].

\footnotetext{
* Corresponding author: svetlana-nngu@mail.ru
} 


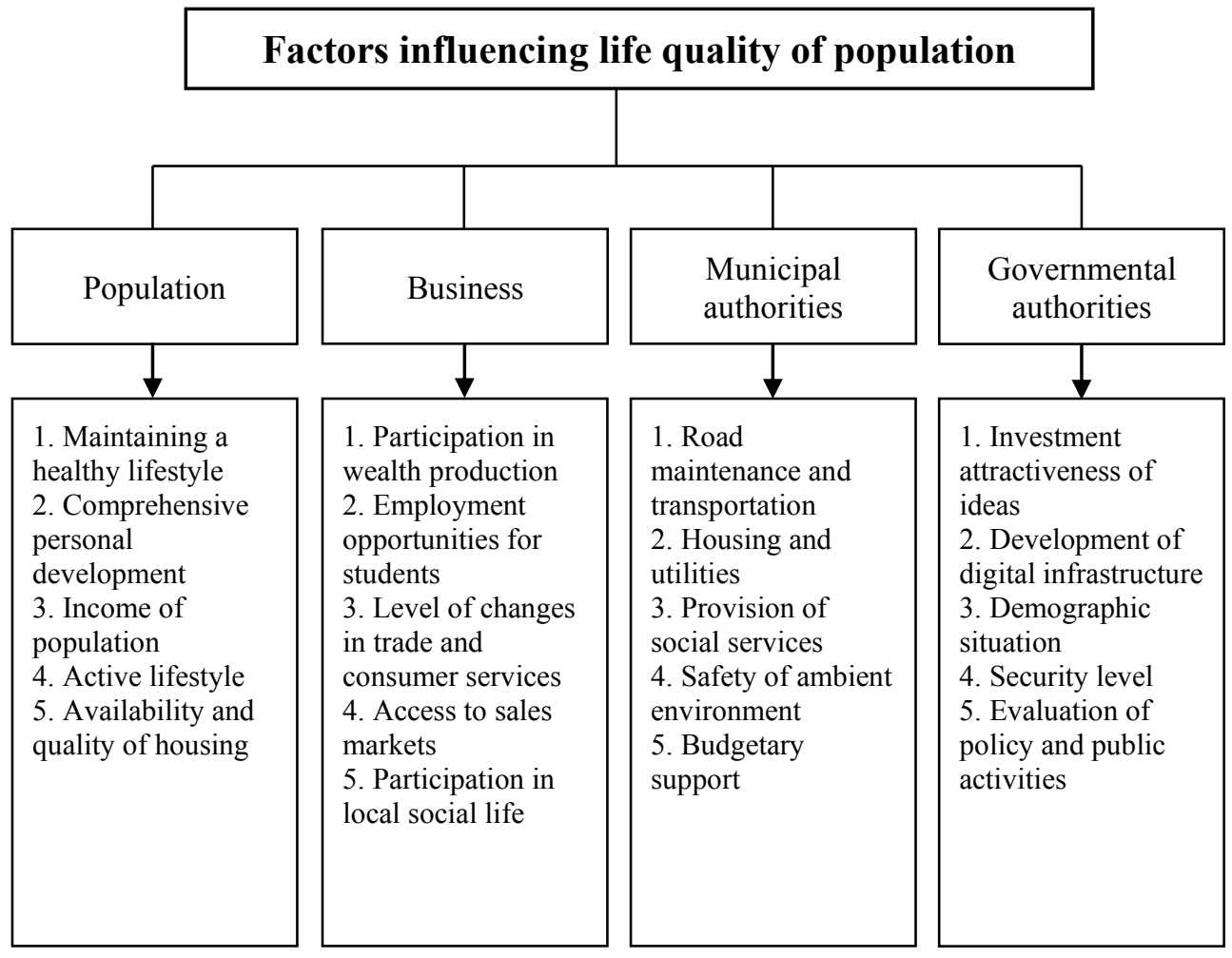

Fig. 1. Factors influencing life quality of students.

\section{Results and discussion}

Each entity, while being changed, indirectly impacts the life quality of population, including students, thus transforming the system of criterion indicators [1]. Formation of digital economy in Russia is related with adjustments in administrative territorial arrangement, specification of power of authorities of Russia subjects of horizontal and vertical levels, having clearly directed impact on economy and growth of life quality of population [2]. The tasks of research and socio-economic development of the Russian Federation for the period up to the year of 2024, according to which the appropriate programs have been developed, have clear social orientation [3]. In the frames of Digital Economy national program, the communication transformations of the highest importance are being carried out [4]. These processes are accelerated due to positive contribution of the isolation related with the pandemic. During the pandemic the implementation of innovation technologies in all areas of life has been initiated, including education [5]. In the world practice, online learning becomes an inherent portion of education and quite convenient form of interaction [6], and the digital transformation of education was mentioned by the President of the Russian Federation among the national targets of development in the period up to the year of 2030. Due to the demand for new professional competences, the Russian government has developed and is implementing the program of personal digital certificates.

High interest is attracted to evaluation of the results of the use of digital technologies in education under the conditions of emergency transfer to online learning in terms of changes of life quality of students. With this aim, the main positive changes were analyzed mentioned by the students of a leading Russian university upon obtaining online educational services (Fig. 2). 


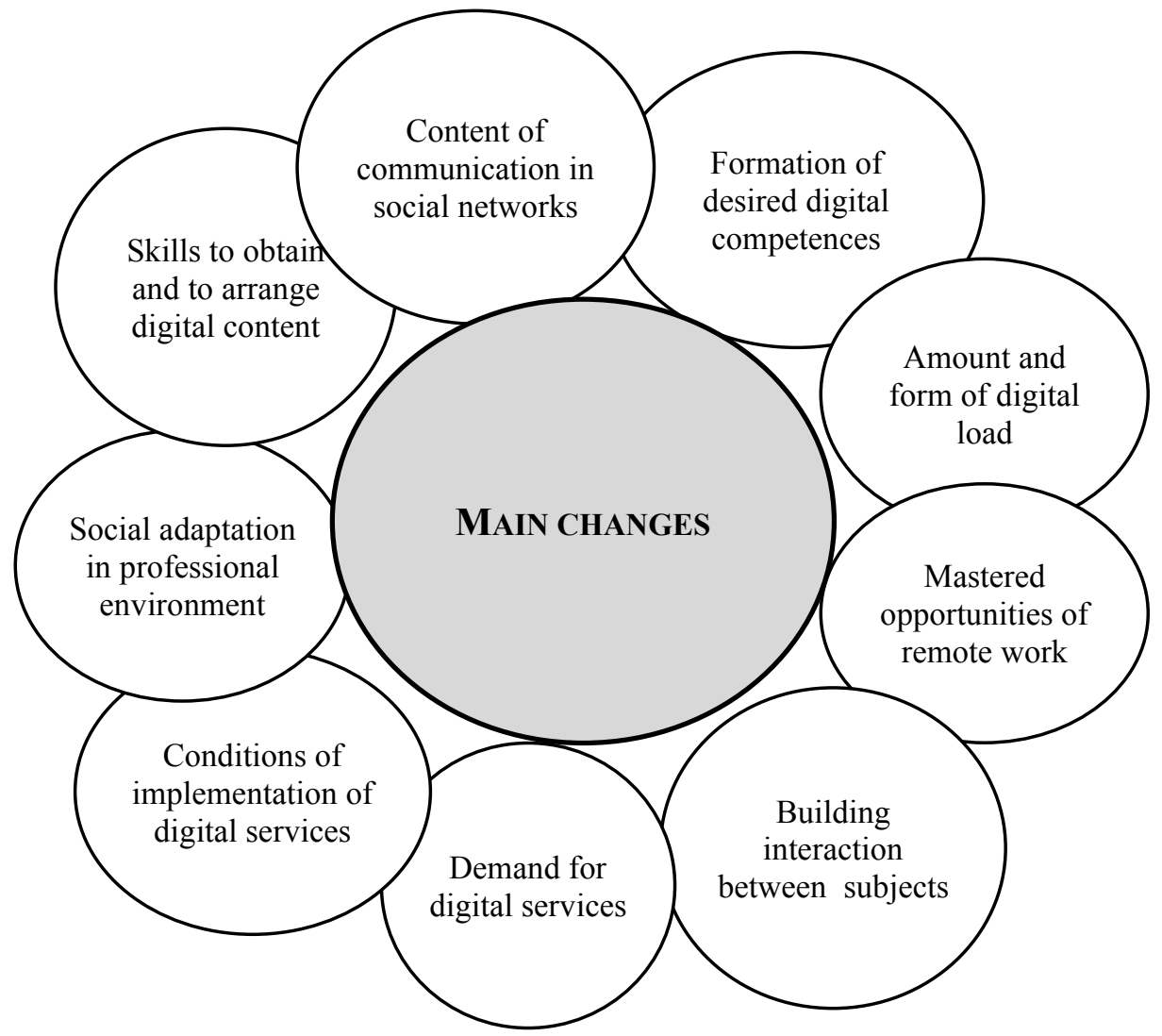

Fig. 2. Main positive changes mentioned by students during the pandemic upon obtaining online educational services.

The students mention opportunity of creative cognition of learning material in online format, as well as implementation of sufficiently high level of scientific thinking. One of the most important drawbacks of online education in many countries is comprised of technical issues [7]. In this regard, it is required to create peculiar conditions for young people to implement outstanding capabilities in the field of information technologies [8]. New digital technologies in education help to form the desired digital competences, to rapidly perform practical tasks with high quality, thus changing lifestyle of students. The most demanded are the event systems, storytelling, gamification [9]. The online format becomes a source of creativity, it facilitates development of wide range of professional competences as opposed to conventional approach, where the main element of education is memorizing [10]. However, at the same time, the online education exerts significant influence on psychological state of students [11].

Figure 3 illustrates the changes in life quality of students during the pandemic upon obtaining online educational services. 


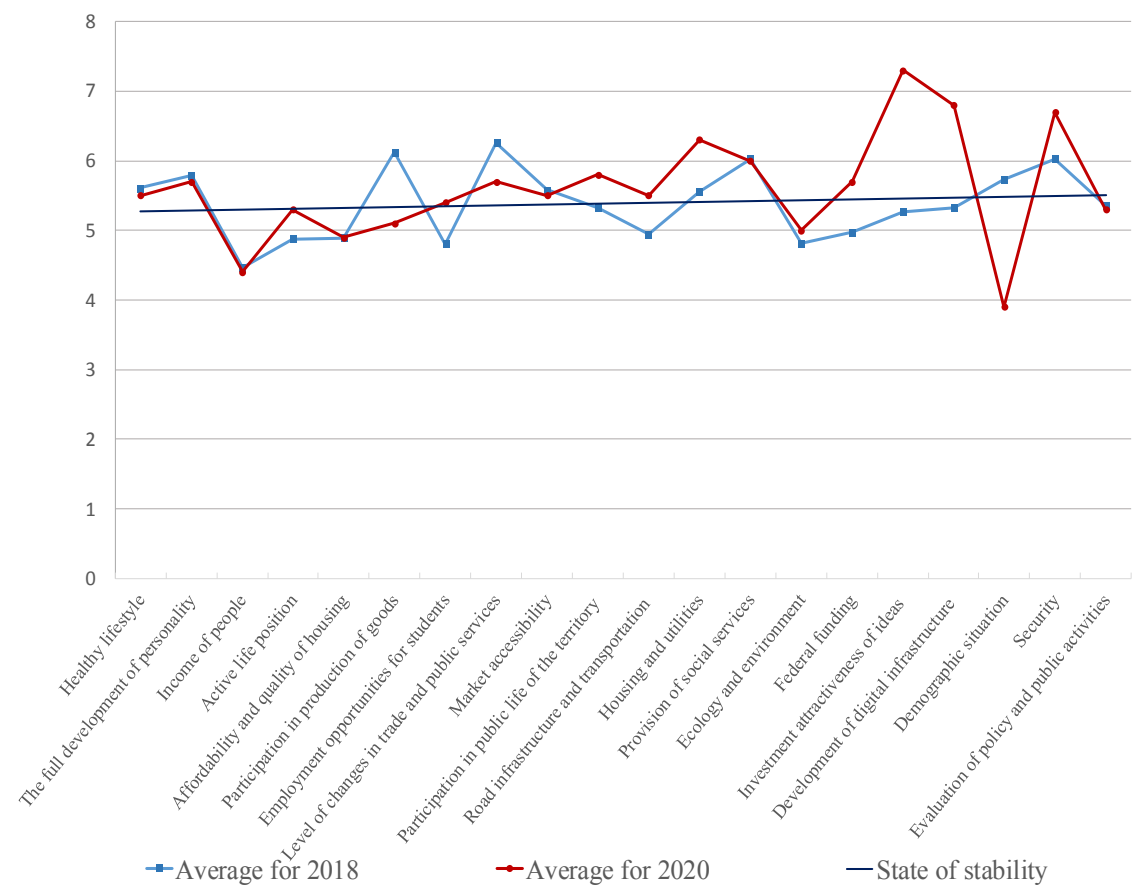

Fig. 3. Evaluation of changes in the factors influencing the life quality of students.

Sociological evaluation of life quality of students was based on 10 score system and was arranged as follows: 5 scores were assigned to the indicator not changed in comparison with 2019, higher than 5 scores - changed for the better, lower than 5 scores - changed for the worse. The performed sociological survey has demonstrated the changes in life quality of young people during the pandemic. There was observed the increase in the indicators of Healthy lifestyle, Comprehensive personal development, and Active lifestyle, which were characteristic for increase in political activity. It has been mentioned that communication among social groups transferred into another format (social networks, Internet) [12] and had a positive effect on relations between economic entities and social institutions. The indicator of Trade and consumer services was estimated higher in comparison with the previous year. Opportunities of students' employment had been expanded due to wider range of opportunities to implement professional competences in digital environment.

No complaints to Housing and utilities were mentioned, because the interaction with authorities of various levels was simplified, and the use of numerous services in the frames of digital economy eliminated official red tape. Social adaptation in professional environment became simpler, social inequality was excluded as only the level of professional competences and skills of digital technologies were needed [13]. However, at the same time, digitization limited opportunities to communicate and to create family relations, which was directly related with demographic situation. The students mentioned decrease in the level of income and availability of housing, even when mortgage rates were lowered. While considering the models of factor approach to life quality of population, the inequality became apparent regarding labor incomes and incomes received after sales of other factors of production in economy [14]. 


\section{Conclusion}

In Russia great attention is paid by the government to creation of conditions of entrepreneurship, which positively characterizes the growth in investment attractiveness of youth ideas. During formation of digital economy, the global competitive infrastructure is being developed, and the life quality is manifested in correlations between changes and meaningful values [15] based on social motivation of young people to progress.

\section{References}

1. S.G. Zakharova, Vestnik of Lobachevsky State University of Nizhni Novgorod. Series: Social Sciences, 3(43), 7-16 (2016)

2. A.A. Ivanov, S.N. Yashin, N.D. Ivanova, Analiz sovremennogo sostoyaniya $i$ formirovaniya tsifrovoy ekonomiki Rossii, in Proceedings of the Scientific and Practical Conference with Foreign Participation Tsifrovaya Transformatsiya Ekonomiki i Promyshlennosti [Digital Transformation of the Economy and Industry], Peter the Great St. Petersburg Polytechnic University, 20-22 June 2019, Saint Petersburg, Russia, 104-113 (2019)

3. Ukaz Prezidenta ot 07.05.2018 № 204 (red. of 21.07.2020) “O natsional’nykh tselyakh i strategicheskikh zadachakh razvitiya Rossiyskoy Federatsii na period do 2024 goda" [Decree of the President of 07.05.2018 No. 204 (as amended on 21.07.2020) "On national goals and strategic objectives of the development of the Russian Federation for the period up to 2024"]. Accessed on: December 10, 2020. [Online]. Available: http://www.kremlin.ru/acts/bank/43027

4. O sisteme realizatsii programmy “Tsifrovaya ekonomika Rossiyskoy Federatsii”. Postanovleniye Pravitel'stva RF ot 28.09.2017 № 1030 [On the system of implementation of the program "Digital Economy of the Russian Federation". Resolution of the Government of the Russian Federation of September 28, 2017 No. 1030]. Accessed on: December 10, 2020. [Online]. Available: http://government.ru/docs/29003/

5. L. Giordano, L. Cipollaro, F. Migliorini, N. Maffulli, The Surgeon, Nov 12, 1-8 (2020). https://doi.org/10.1016/j.surge.2020.09.014

6. H. S. Zaghloul, D. S. Mahdy, The Education and Science Journal, 22(8), 41-74 (2020). https://doi.org/10.17853 / 1994-5639-2020-8-40-74

7. E. Hussein, S. Daoud, H. Alrabaiah, R. Badawi, Children and Youth Services Review, 119, 1-7 (2020). https://doi.org/10.1016/j.childyouth.2020.105699

8. E. K. Khenner, C. Frieze, O. Zane, The Education and Science Journal, 22(8), 189-206 (2020). https://doi.org/10.17853 / 1994-5639-2020-8-189-206.

9. E.O. Chernyh, Ekonomika, Predprinimatelstvo i Pravo [Economy, Business and Law], 10(11), 2827-2848 (2020). http://doi.org/10.18334/epp.10.11.111127.

10. L.F. Sukhodoeva, J. Coe, Bulletin of Lobachevsky State University of Nizhni Novgorod. Series: Social Sciences, 2-1, 278-282 (2014)

11. N. Hasan, Y. Bao, Children and Youth Services Review, 118, 105355 (2020). https://doi.org/10.1016/j.childyouth.2020.105355

12. P. Aguilera-Hermida, International Journal of Educational Research Open, 1, 100011 (2020). https://doi.org/10.1016/j.ijedro.2020.100011

13. V. Ratten, P. Jones, The International Journal of Management Education, 19(1), 100432 (2021). https://doi.org/10.1016/j.ijme.2020.100432 
14. S. G. Zakharova, International Journal of Professional Science, 1, 33-40 (2017)

15. T. Radošević, International Journal for Quality Research, 12(3), 723-740 (2018). https://doi.org/10.18421/IJQR12.03-11 